\title{
Detection of virulence genes in Malaysian Shigella species by multiplex PCR assay
}

\author{
Kwai Lin Thong*1, Susan Ling Ling Hoe ${ }^{1}$, SD Puthucheary ${ }^{2}$ and Rohani Md \\ Yasin $^{3}$
}

Address: ${ }^{1}$ Institute of Biological Sciences, Faculty of Science, University of Malaya, 50603 Kuala Lumpur, Malaysia, ${ }^{2}$ Department of Medical Microbiology, Faculty of Medicine, University of Malaya, 50603 Kuala Lumpur, Malaysia and 3 Institute for Medical Research, Jalan Pahang, 50588 Kuala Lumpur, Malaysia

Email: Kwai Lin Thong* - thongkl@um.edu.my; Susan Ling Ling Hoe - susanllhoe@yahoo.com; SD Puthucheary - puthu@um.edu.my; Rohani Md Yasin - rohani@imr.gov.my

* Corresponding author

Published: 14 February 2005

BMC Infectious Diseases 2005, 5:8 doi:10.1 I86/147/-2334-5-8

This article is available from: http://www.biomedcentral.com/I47/ -2334/5/8

(C) 2005 Thong et al; licensee BioMed Central Ltd.

This is an Open Access article distributed under the terms of the Creative Commons Attribution License (http://creativecommons.org/licenses/by/2.0), which permits unrestricted use, distribution, and reproduction in any medium, provided the original work is properly cited.
Received: 18 August 2004

Accepted: 14 February 2005

\begin{abstract}
Background: In Malaysia, Shigella spp. was reported to be the third commonest bacterial agent responsible for childhood diarrhoea. Currently, isolation of the bacterium and confirmation of the disease by microbiological and biochemical methods remain as the "gold standard". This study aimed to detect the prevalence of four Shigella virulence genes present concurrently, in randomly selected Malaysian strains via a rapid multiplex PCR (mPCR) assay.
\end{abstract}

Methods: A mPCR assay was designed for the simultaneous detection of chromosomal- and plasmid-encoded virulence genes (set IA, set/B, ial and ipaH) in Shigella spp. One hundred and ten Malaysian strains (1997-2000) isolated from patients from various government hospitals were used. Reproducibility and sensitivity of the assay were also evaluated. Applicability of the mPCR in clinical settings was tested with spiked faeces following preincubation in brain heart infusion (BHI) broth.

Results: The $i p a H$ sequence was present in all the strains, while each of the set $/ A$, set $/ B$ and ial gene was present in $40 \%$ of the strains tested. Reproducibility of the mPCR assay was $100 \%$ and none of the non-Shigella pathogens tested in this study were amplified. The mPCR could detect 100 colony-forming units (cfu) of shigellae per reaction mixture in spiked faeces following preincubation.

Conclusions: The mPCR system is reproducible, sensitive and is able to identify pathogenic strains of shigellae irrespective of the locality of the virulence genes. It can be easily performed with a high throughput to give a presumptive identification of the causal pathogen.

\section{Background}

Members of the genus Shigella, namely S. flexneri, S. dysenteriae, S. sonnei and $S$. boydii have caused and continue to be responsible for mortality and/or morbidity in high risk populations such as children under five years of age, senior citizens, toddlers in day-care centres, patients in custodial institutions, homosexual men and, war- and famine-engulfed people. Yearly episodes of shigellosis 
globally have been estimated to be 164.7 million and of these, 163.2 million were in developing countries and the remaining in industrialized nations. The mortality rate was approximately $0.7 \%[1]$. A recent study by Lee \& Puthucheary [2] on bacterial enteropathogens in childhood diarrhoea in a Malaysian urban hospital showed that Shigella spp. was the third most common bacteria isolated. S. flexneri and S. dysenteriae type 1 infections are usually characterized by frequent passage of small amounts of stool and mucus or blood. At times, watery stool followed by typical dysenteric stool maybe present with $S$. dysenteriae type 1 infection. S. sonnei and S. boydii infections are less severe with watery faeces but little mucus or blood.

Shigellosis is usually a self-limiting infection, however when it subsides, the intestinal ulcers heal with scar tissue formation. Uncomplicated recovery is usual and the organisms rarely cause other types of infections. Adversely, in 3 to $50 \%$ of cases, depending on the virulence of the strain, the nutritional and immune status of the host, the initial infection maybe followed by neurological complications or kidney failure. Serious complications do occur at greatest frequencies in malnourished infants, toddlers, older adults and immunocompromised individuals $[3,4]$.

Virulence genes responsible for the pathogenesis of shigellosis may be located in the chromosome or on the inv plasmid borne by the organism. They are often multifactorial and coordinately regulated, and the genes tend to be clustered in the genome. Previously reported PCR-based detection methods concentrated mainly on the ipaH gene alone $[5,6]$ or on $i p a H$ and ial genes in two separate PCR assays $[7,8]$. As $i a l$ is found on the large inv plasmid which is prone to loss or deletions, this gene-based detection may give false negative results. ipa $H$, on the other hand, is present on both the Shigella chromosome and on a large plasmid and hence, it is a more stable gene to detect. However, the sole presence of $i p a H$ is not an absolute indicator of virulence as loss or deletion of the plasmid renders the bacterium noninvasive and therefore, avirulent. set $1 \mathrm{~A}$ and $\operatorname{set} 1 \mathrm{~B}$ are chromosomal genes encoding Shigella enterotoxin 1 (ShET1), which cause the watery phase of diarrhoea in shigellosis $[9,10]$. $i a l$ and $i p a H$ are responsible for directing epithelial cell penetration by the bacterium and for the modification of host response to infection, respectively [11-13].

Here, we describe the application of a multiplex PCR (mPCR) design for simultaneous detection of four virulence genes (set1A, set1B, ial and ipaH) in Shigella spp. and to determine the prevalence of these virulence genes in a random selection of Malaysian Shigella strains.

\section{Methods}

\section{Bacterial strains and growth conditions}

A total of 110 Shigella strains of S. flexneri $(\mathrm{n}=84), S$. sonnei $(\mathrm{n}=15), S$. dysenteriae $(\mathrm{n}=10)$ and $S$. boydii $(\mathrm{n}=1)$ were used in this study. These strains were isolated from patients with diarrhoea in Peninsular Malaysia from 1997-2000, and were provided by the Institute for Medical Research (IMR), Malaysia. Serotyping of the strains (Shigella antisera from Mast Diagnostics, UK) was carried out by the Bacteriological Unit, IMR. All the strains were checked on Salmonella-Shigella (SS) agar before being transferred to Luria Bertani (LB) agar plate, incubated overnight at $37^{\circ} \mathrm{C}$ for subsequent screening of virulenceassociated genes. All strains were stored at $-20^{\circ} \mathrm{C}$ in $\mathrm{LB}$ broth containing 15\% glycerol.

\section{Development of $\mathrm{mPCR}$}

Boiled suspension of bacterial cells was used as DNA template. Previously described primers, obtained from Integrated DNA Techs, USA, for detection of the four virulence genes were applied to the template $[8,14,15]$ (Table 1). Prior to combining all the four primer sets in an mPCR, each pair of primers was optimized singly in separate PCR assays. A typical $25-\mu \mathrm{l}$ PCR reaction mixture for every primer set consisted of 1x PCR buffer B (Promega, USA), $4 \mathrm{mM} \mathrm{MgCl} 2,130 \mu \mathrm{M}$ of each deoxynucleotide (dNTP), $0.5 \mu \mathrm{M}$ of each primer, $1 \mathrm{U}$ of Taq DNA polymerase (Promega, USA) and $2 \mu \mathrm{l}$ of DNA template. Amplifications were carried out using a Robocycler Gradient 40 Temperature Cycler (Strategene Cloning Systems, USA). The cycling conditions were an initial denaturation at $95^{\circ} \mathrm{C}$ for $5 \mathrm{~min}$, template denaturation at $95^{\circ} \mathrm{C}$ for $50 \mathrm{~s}$, annealing at $55^{\circ} \mathrm{C}$ for $1.5 \mathrm{~min}$, and extension at $72^{\circ} \mathrm{C}$ for 2 min for a total of 30 cycles, with a final extension at $72^{\circ} \mathrm{C}$ for $7 \mathrm{~min}$.

Based on the results of individual priming, an MPCR was designed. Various parameters such as concentrations of primers $(0.5-0.8 \mu \mathrm{M}), \mathrm{MgCl}_{2}(2$ to $4 \mu \mathrm{M})$, Taq DNA polymerase (0.6 to $4 \mathrm{U}$ ) and dNTPs (100-150 $\mu \mathrm{M})$ and buffer strength (1.4X to $2.4 \mathrm{X})$ were tested. The simultaneous gene amplifications were performed in a reaction volume of $25 \mu \mathrm{l}$ consisting of 1.8X PCR buffer B (Promega, USA), $4 \mathrm{mM} \mathrm{MgCl}_{2}, 130 \mu \mathrm{M}$ of each dNTP, $0.3 \mu \mathrm{M}$ of each ShET1B primer, Shig1 and Shig2 primers, $0.5 \mu \mathrm{M}$ of each ShET1A and ial primers, 1 U of Taq DNA polymerase (Promega, USA) and $2 \mu \mathrm{l}$ of DNA template. All the reaction mixtures were overlaid with $20 \mu$ l of sterile mineral oil. Amplifications were similarly carried out as above.

After initial screening, strain TH13/00 (S. flexneri 2a) was chosen as a positive control for PCR assays. A negative control using sterile distilled water as template was included in every PCR assay. The DNA fragments were separated in $2 \%$ agarose gel. 
Table I: Primers used to identify various virulence-associated genes of Shigella spp.

\begin{tabular}{|c|c|c|c|c|}
\hline Primer & Virulence gene & Nucleotide sequences $\left(5^{\prime} \rightarrow 3^{\prime}\right)$ & Size of amplicon (bp) & Reference \\
\hline ShETIA & set/A & $\begin{array}{l}\text { TCA CGC TAC CAT CAA } \\
\text { AGA } \\
\text { TAT CCC CCT TTG GTG } \\
\text { GTA }\end{array}$ & 309 & 14 \\
\hline ShETIB & $\operatorname{set} / B$ & $\begin{array}{l}\text { GTG AAC CTG CTG CCG } \\
\text { ATA TC } \\
\text { ATT TGT GGA TAA AAA } \\
\text { TGA CG }\end{array}$ & 147 & 14 \\
\hline ial & ial & $\begin{array}{l}\text { CTG GAT GGT ATG GTG } \\
\text { AGG } \\
\text { GGA GGC CAA CAA TTA } \\
\text { TTT CC }\end{array}$ & 320 & 15 \\
\hline Shigl & $\mathrm{ipaH}$ & $\begin{array}{l}\text { TGG AAA AAC TCA GTG } \\
\text { CCT CT }\end{array}$ & 423 & 8 \\
\hline Shig2 & & $\begin{array}{l}\text { CCA GTC CGT AAA TTC } \\
\text { ATT CT }\end{array}$ & & \\
\hline
\end{tabular}

\section{Reproducibility test}

The MPCR assay was repeated at least twice with 28 strains to determine the reproducibility of the results, whereby the DNA template of a particular strain was freshly prepared for each repeat.

\section{Specificity test}

The specificity of the MPCR assay was tested with 12 other non-Shigella pathogens: Enterobacter cloacae, Salmonella Paratyphi A (ATCC 9281), S. Paratyphi C, S. Typhimurium, S. Enteritidis, S. Typhi (ATCC 7251), Listeria monocytogenes, Pseudomonas aeruginosa, Klebsiella pneumoniae, Citrobacter freundii, Escherichia coli O157:H7 and E. coli O78:H11.

\section{Faecal spiking and sensitivity test}

This was based on a modification of that described by Chiu and Ou [16]. Approximately $0.2 \mathrm{~g}$ of faeces from a healthy individual was suspended in $1 \mathrm{ml}$ of brain heart infusion (BHI) (Oxoid Ltd., UK) and diluted 10-fold. Then, $1 \mathrm{ml}$ of the diluted faecal suspension was inoculated into $4 \mathrm{ml}$ of $\mathrm{BHI}$ and vortexed to obtain a homogenous mixture of broth-faecal suspension. Meanwhile, an overnight culture of $S$. flexneri 2 a was harvested and serially diluted 10 -fold with BHI. Then, $250 \mu \mathrm{l}$ of each dilution of cell culture was mixed with $250 \mu$ of the brothfaecal suspension and $500 \mu \mathrm{l}$ of BHI in a new eppendorf tube. The tubes were vortexed and preincubated at $37^{\circ} \mathrm{C}$ for $4 \mathrm{~h}$ without shaking. Simultaneously, $100 \mu \mathrm{l}$ of each diluted culture was plated on LB agar (Oxoid Ltd., UK) to determine the number of viable bacteria in each dilution. After preincubation, MPCR assay was performed on the boiled lysates of each diluted culture. A pure culture of $S$. flexneri $2 \mathrm{a}$ (TH13/00) and an unspiked faecal sample served as positive and negative controls.. The test was repeated with a spiked faecal sample of another healthy individual, and the average detection limit was reported.

\section{Screening of clinical specimens}

$0.2 \mathrm{~g}$ of each faecal sample from 10 patients suffering from diarrhoea in a local tertiary University Hospital was suspended in $1 \mathrm{ml}$ of BHI and diluted 10-fold. A volume of $250 \mu \mathrm{l}$ of broth-faecal suspension was inoculated into $5 \mathrm{ml}$ of $\mathrm{BHI}$ and preincubated at $37^{\circ} \mathrm{C}$ for $4 \mathrm{~h}$ without shaking. Concurrently, $100 \mu$ of the suspension was plated onto MacConkey and SS agar plates and incubated overnight at $37^{\circ} \mathrm{C}$. mPCR assay was performed on the boiled lysate of the broth-faecal suspension after preincubation. A pure culture of strain TH13/00 and a Shigellaspiked faecal sample served as a positive control, whilst a PCR reaction mixture without bacterial DNA template and an unspiked faecal sample from a healthy individual acted as a negative control.

\section{Results \\ Optimization strategies}

A monoplex PCR for each primer set was initially carried out based on a published report [17]. Although the concentrations of $\mathrm{MgCl}_{2}$ (3 mM), dNTP (400 $\mu \mathrm{M}$ each) and primers ( $1 \mu \mathrm{M}$ each) were used as recommended, unspecific bands were present together with intense primerdimers. In order to reduce the background noise and primer-dimers, concentrations of $0.5 \mu \mathrm{M}$ of each primer and $200 \mu \mathrm{M}$ of each dNTP were used. Further optimizations of $\mathrm{MgCl}_{2}$ concentrations (2 to $4 \mu \mathrm{M}$ ) and dNTP $(100,130$ and $150 \mu \mathrm{M}$ each) gave intense amplicons with a clean background in each monoplex amplification (Fig 1, lanes 1-4). 


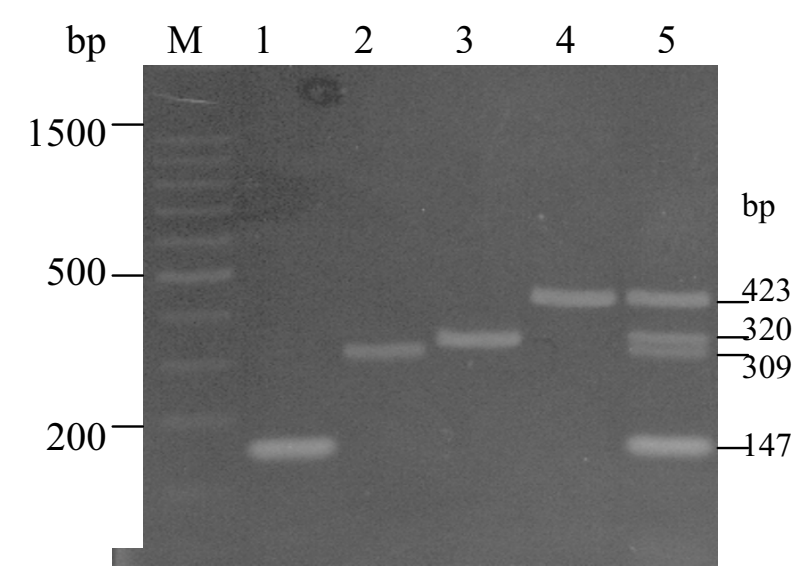

Figure I

Ethidium bromide-stained agarose gel showing PCR products. Lane M, I00-bp DNA ladder (Promega); lane I, set I B gene product; lane 2, set IA gene product; lane 3, ial gene product; lane 4, ipaH gene product; lane $5, \mathrm{mPCR}$ product.

Initial attempts to amplify equally all the four genes in a single reaction using the reaction condition in monoplex PCR were not successful. A common practice in mPCRs involving any non-amplification of a required gene ('weak locus') is to increase the amount of primers of the gene at same time with a decrease of the amount of primers for all the loci that can be amplified, especially those with strong amplifications. Hence, the concentrations of primers for both ipaH (Shig) and set1B (ShET1B) were reduced to $0.3 \mu \mathrm{M}$ each and the primers for both set $1 \mathrm{~A}$ (ShET1A) and ial (ial) genes were maintained at $0.5 \mu \mathrm{M}$ each. Following optimization of the concentrations of Taq DNA polymerase $(0.6$ to $4 \mathrm{U} / 25 \mu \mathrm{L})$, buffer strength $(1.4$ $\mathrm{X}$ to $2.4 \mathrm{X}$ ), dNTPs (140 to $220 \mu \mathrm{M}$ ) and annealing temperatures ( 49 to $59^{\circ} \mathrm{C}$ ) (at a constant $\mathrm{MgCl}_{2}$ concentration of $4 \mathrm{mM}$ ), a more uniform amplification of all the genes with no background noise was obtained (Fig. 1 lane 5) at a final buffer concentration of $1.8 \mathrm{X}, 1$ U Taq DNA polymerase, $130 \mu \mathrm{M}$ dNTP each and annealing temperature of $55^{\circ} \mathrm{C}$.

\section{Prevalence of virulence genes in the Malaysian strains}

All the 110 strains of Shigella spp. tested showed the presence of ipaH (Table 2). Conversely, only $41 \%$ of the strains had both set $1 A$ and $\operatorname{set} 1 B$ genes, and ial gene. Almost all the Shigella strains tested positive for the tandem genes $(87 \%)$ belonged to $S$. flexneri 2a serotype. Among the predominant strains of Shigella flexneri in Malaysia, ial was found in serotypes $4 a, 6,3 a, 2 a, 1 a$ and
Table 2: Prevalence of the four virulence-associated genes in Malaysian Shigella spp.

\begin{tabular}{llllll}
\hline Serotype & $\begin{array}{l}\text { Total } \\
\text { strains }\end{array}$ & $\begin{array}{l}\text { set IB } \\
(\%)\end{array}$ & $\begin{array}{l}\text { set IA } \\
(\%)\end{array}$ & $\begin{array}{l}\text { ial } \\
(\%)\end{array}$ & $\begin{array}{l}\text { ipaH } \\
(\%)\end{array}$ \\
\hline S. flexneri Ia & 3 & $0(0)$ & $0(0)$ & $1(33)$ & $3(100)$ \\
Ib & 3 & $0(0)$ & $0(0)$ & $0(0)$ & $3(100)$ \\
2a & 47 & $4 I(87)$ & $4 I(87)$ & $19(40)$ & $47(100)$ \\
3a & 18 & $3(17)$ & $3(17)$ & $12(67)$ & $18(100)$ \\
3c & 10 & $0(0)$ & $0(0)$ & $1(10)$ & $10(100)$ \\
4a & 1 & $1(100)$ & $1(100)$ & $1(100)$ & $1(100)$ \\
6 & 1 & $0(0)$ & $0(0)$ & $1(100)$ & $1(100)$ \\
y & 1 & $0(0)$ & $0(0)$ & $0(0)$ & $1(100)$ \\
S. sonnei & 15 & $0(0)$ & $0(0)$ & $2(13)$ & $15(100)$ \\
S. dysenteriae 2 & 10 & $0(0)$ & $0(0)$ & $8(80)$ & $10(100)$ \\
S. boydii 6 & 1 & $0(0)$ & $0(0)$ & $0(0)$ & $1(100)$ \\
\hline Total & 110 & 45 & 45 & 45 & 110 \\
\hline
\end{tabular}

3c. All the four genes were present only in S. flexneri 2 a and $3 a$.

\section{Reproducibility}

Reproducibility for the detection ofset1A, set1B, ial and $i p a H$ genes assayed in the mPCR was $100 \%$. None of the non-Shigella strains tested gave any amplification (data not shown).

\section{Sensitivity}

The MPCR assay was tested on 10-fold dilutions of an overnight culture of $S$. flexneri $2 \mathrm{a}$. All the four virulenceassociated genes were detected until $10^{-3}$ dilutions (data not shown). This was equivalent to $2.45 \times 10^{5}$ lysate or a minimum of $490 \mathrm{cfu}$ of shigellae per $25-\mu \mathrm{LmPCR}$ reaction.

\section{Faecal spiking and sensitivity}

An initial experiment using undiluted spiked faecal sample failed to give any PCR amplification (data not shown). When the faecal suspension was diluted and preincubated in $\mathrm{BHI}$ for $4 \mathrm{~h}$, the mPCR assay was successful in detecting the presence of the four virulence genes at an average concentration of $5.0 \times 10^{4}$ colony-forming units (cfu) shigellae $\mathrm{ml}^{-1}$ or approximately $100 \mathrm{cfu}$ per reaction mixture (Fig. 2 lane 8).

\section{Clinical specimens}

A preliminary study on the efficacy of the MPCR assay in the direct detection of the aforementioned Shigella virulence genes on faecal samples was tested on ten diarrhoeal patients. No mPCR product was detected although both the positive controls had amplifications. By conventional culture method, there was no growth of Shigella on the LB, MacConkey and SS agar plates. 


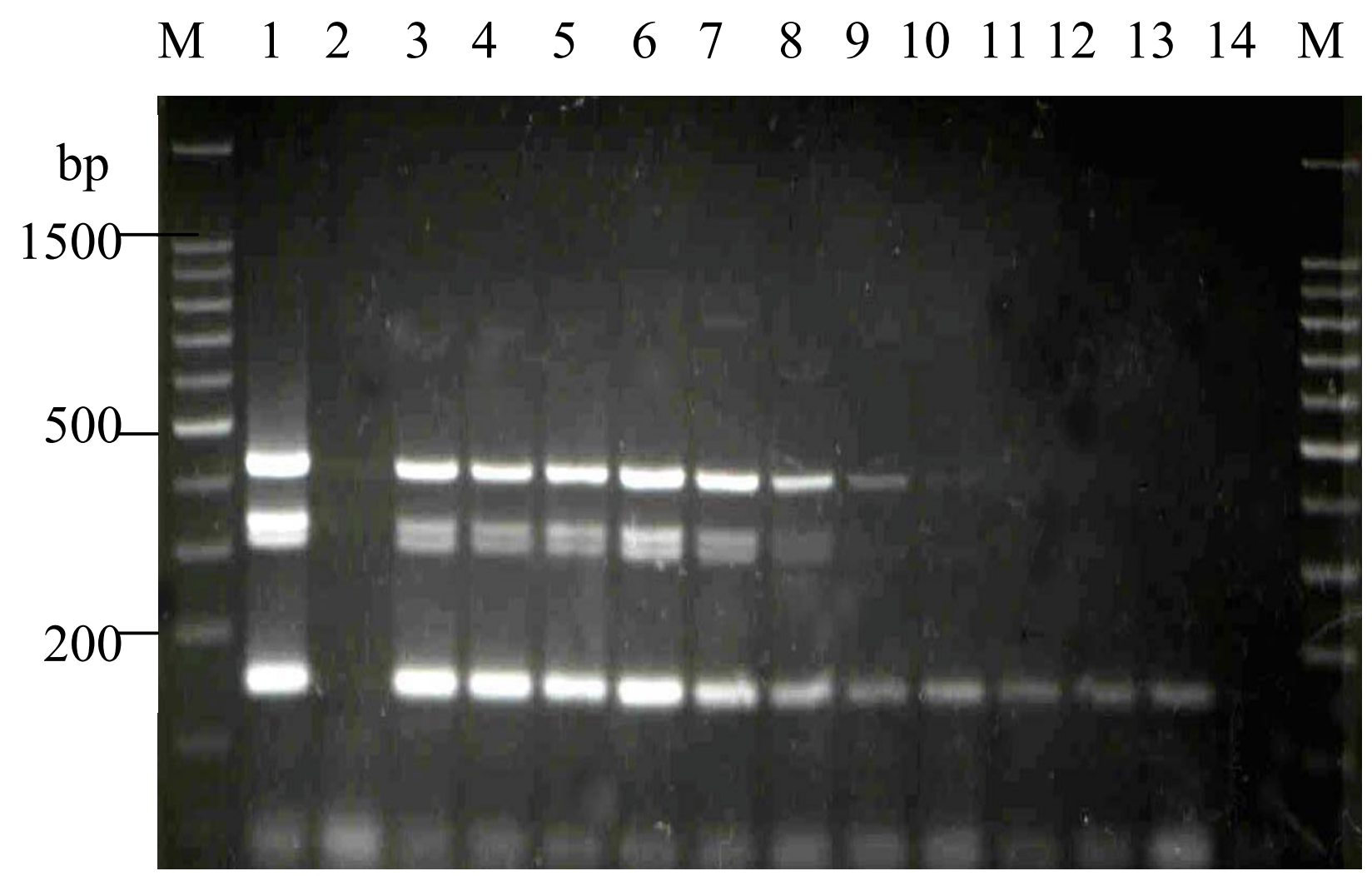

Figure 2

Faecal-spiking and sensitivity result of $\mathbf{m P C R}$. Lane M, I00-bp DNA ladder (Promega, USA); lane I, THI3/00 (positive control); lane 2, unspiked faeces (negative control); lane 3, undiluted spiked faeces; lane 4, $10^{-1}$ dilution; lane 5, $10^{-2}$ dilution; lane 6, $10^{-3}$ dilution; lane 7, 10-4 dilution; lane 8, $10^{-5}$ dilution; lane 9, $10^{-6}$ dilution; lane 10, $10^{-7}$ dilution; lane I I, I0-8 dilution; lane I 2, 10-9 dilution; lane 13, 10-10 dilution; lane 14, "water blank".

\section{Discussion}

Numerous studies had been performed to detect virulence genes in Shigella by monoplex PCRs $[8,17,18]$. Studies involving the combination of chromosomal- and plasmid-encoded virulence genes in a single assay for Shigella detection, on the other hand, are scarce. Although the optimization of mPCR is more tedious and difficult to achieve than monoplexes, the ease of screening a large number of specimens, once the system is optimized, far outweighs the initial problems. The present mPCR system encompasses the presence of virulence genes found in the Shigella chromosome and on the large inv plasmid. Hence, it can determine if the pathogenesis of a particular strain is attributable to its chromosome or the plasmid, or if the strain is still invasive or otherwise, in a single reaction.
Initially, the monoplex PCRs were carried out following reaction conditions as proposed by a previous report [17]. However, we could not reproduce their results and hence had to modify the PCR conditions. Our failure to reproduce identical results despite using similar reagent concentrations and amplification conditions maybe attributed to the different makes of PCR reagents and primers used. Broude et al. [19] had compared amplification efficiencies of two commercial Taq DNA polymerases and found that they displayed different specificity in PCR.

Preferential amplification of one target sequence over another is a known phenomenon in mPCRs and it is usually overcome by increasing the amount of primers for the weaker amplification simultaneously with a decrease of 
primer concentrations for the stronger amplification. Buffer concentration may also affect mPCR amplifications despite it being seldom considered during monoplex optimization works [20]. Upon adjustment of primers and buffer concentrations, specific and consistent amplification of all the genes in the multiplex combination was achieved.

Although other studies have demonstrated the presence of ial and ipaH in strains of enteroinvasive Escherichia coli (EIEC) $[11,13,21]$, we had not applied the mPCR assay to EIEC strains. It is unfortunate that these strains were not available for our study as EIEC gives rise to similar illness as Shigellosis.

Our study supported the observations of Noriega et al. [9] and Vargas et al. [17] in local Shigella strains. Their studies showed that both set1 A and set1B were present exclusively in $S$. flexneri $2 \mathrm{a}$. The complete correlation between the presence of both set $1 A$ and $\operatorname{set} 1 B$ showed that both genes are indeed found in tandem in the Shigella genome. In this study, almost all the Shigella strains positive for the presence of set1A and set1B (41/45 strains) belonged to $S$. flexneri $2 \mathrm{a}$, thus confirming previous works that both genes are highly conserved in this particular serotype [14].

Both the prevalence of $i a l$ and $i p a H$ were independent of the four different species of Shigella tested. Though both ial and ipaH are responsible for invasion-related processes and are found on the inv plasmid, the ial gene cluster resides near a region of the plasmid, which is a hot spot for spontaneous deletions [22]. This probably explains the lower prevalence of ial (45/110 strains) than ipaH (110/110 strains) in the Malaysian Shigella strains. Since invasiveness is a prerequisite for virulence in shigellae and since most of these virulence genes are located on the large plasmid, these strains would have possessed the plasmid when first isolated from patients. Due to storage/ subculturing, the plasmid might have been lost together with the virulence-associated genes. By virtue of multiple copies being present on both the chromosome and the inv plasmid [23], ipaH seemed to be less compromised by plasmid loss and/or deletions. As the sole presence of $i p a \mathrm{H}$ is not indicative of the invasive phenotype, our mPCR design, which incorporated three other virulence genes, could determine the invasiveness of Shigella strains in epidemiological studies.

Dilution of the faecal sample with BHI was performed to lower the levels of PCR inhibitors such as bilirubin, bile salts and heme in the faeces [16]. An additional step of preincubating the spiked faecal samples also helped to eliminate the natural inhibitors [24]. The short 4-h enrichment step would increase the total number of target sequences caused by more bacterial growth and the over- all detection sensitivity of the assay. Although PCR cannot differentiate between dead and viable bacteria, enrichment helped to dilute the concentrations of dead bacteria, thus reducing the probability of detecting them by the subsequent mPCR assay. The sensitivity level achieved in the study was found to be comparable to other studies. Houng et al. [25] detected up to $7.4 \times 10^{4} \mathrm{cfu}^{\text {shigellae } \mathrm{ml}^{-}}$ ${ }^{1}$ by amplifying the IS 630 sequences in shigella spp.. Yavzori et al. [24] reported a detection level of $10^{4} \mathrm{cfu}$ shigellae per gram of faeces with the use of virF primers. Although it has been reported that ingestion as low as 100 shigellae resulted in clinical disease [26], the highest percentage of volunteers having diarrhoea were administered doses of at least $10^{4}$ viable organisms. Thus, the average detection limit of mPCR described in this study $\left(5.0 \times 10^{4} \mathrm{cfu} / \mathrm{ml}\right)$ is within the common infectious dose for shigellae.

Results from the preliminary clinical screening were promising. Nevertheless, the consideration of other diarrhoeal pathogens being present in the clinical samples cannot be negated. More patient samples are warranted to thoroughly vet the robustness and applicability of the developed mPCR in clinical environments.

One limitation of the present mPCR system is its inability to differentiate Shigella spp., unlike the multiplex reactions based on specific $r f c$ genes developed by Houng et al. [25]. For future research, either $\operatorname{set} 1 A$ or $\operatorname{set} 1 B$ may be omitted from the multiplex system as both genes are shown to exist tandemly. $r f c$ primers of different Shigella origins maybe incorporated to enable the discrimination of Shigella spp. as well as the identification of virulent strains in one assay.

\section{Conclusions}

We conclude that the mPCR system is able to identify pathogenic strains of shigellae irrespective of the locality of the virulence genes. The described assay is reproducible, sensitive, can be easily performed and is able to give a presumptive identification of the causal pathogen, which could be confirmed by culture techniques using selective media. An added advantage would be that EIEC, which gives a similar illness, might also be detected by this method, as EIEC also harbours $i a l$ and ipaH genes.

\section{Competing interests}

The author(s) declare that they have no competing interests.

\section{Authors' contributions}

SLLH carried out the experiments, data analysis and wrote the manuscript. RMY provided the bacterial strains. SDP contributed to the writing of the manuscript. TKL conceived and co-designed the study, provided input for writ- 
ing and supervision of the study. All authors read and approved the final manuscript.

\section{Acknowledgements}

IRPA grant (06-02-03-1007) from the Ministry of Science, Technology and Environment, Malaysia and Vote F (FOI44/2002B) from the University of Malaya, Malaysia, supported this work. We are grateful to Mr. Koh Yin Tee (IMR) for serotyping the bacterial strains.

\section{References}

I. Kotloff KL, Winickoff JP, Ivanoff B, Clemens JD, Swerdlow DL, Sansonetti PJ, Adak GK, Levine MM: Global burden of Shigella infections: implications for vaccine development and implementation of control strategies. Bull World Health Organ 1999, 77:651-666.

2. Lee WS, Puthucheary SD: Bacterial enteropathogens isolated in childhood diarrhoea in Kuala Lumpur - the changing trend. Med J Malaysia 2002, 57:24-30.

3. Salyers AA, Whitt DD: Bacterial pathogenesis: a molecular approach Washington, DC, ASM Press; 1994.

4. Khan AM, Rabbani GH, Faruque ASG, Fuchs GJ: WHO-ORS in treatment of shigellosis. J Diarrhoeal Dis Res 1999, I 7:88-89.

5. Gaudio PA, Sethabutr O, Echeverria P, Hoge CW: Utility of a polymerase chain reaction diagnostic system in a study of the epidemiology of shigellosis among dysentery patients, family contacts and well controls living in a shigellosisendemic area. J Infect Dis 1997, I76:1013-1018.

6. Dutta S, Chatterjee A, Dutta P, Rajendran K, Roy S, Pramanik KC, Bhattacharya SK: Sensitivity and performance characteristics of a direct PCR with stool samples in comparison to conventional techniques for diagnosis of Shigella and enteroinvasive Escherichia coli infection in children with acute diarrhoea in Calcutta, India. J Med Microbiol 200 I, 50:667-674.

7. Sethabutr O, Venkatesan M, Murphy GS, Eampokalap B, Hoge CW, Echeverria $P$ : Detection of shigellae and enteroinvasive Escherichia coli by amplification of the invasive plasmid antigen H DNA sequence in patients with dysentery. J Infect Dis |993, | 67:458-46|.

8. Lüscher D, Altwegg M: Detection of shigellae, enteroinvasive and enterotoxigenic Escherichia coli using the polymerase chain reaction (PCR) in patients returning from tropical countries. Mol Cell Probes 1994, 8:285-290.

9. Noriega FR, Liao FM, Formal SB, Fasano A, Levine MM: Prevalence of Shigella enterotoxin I among Shigella clinical isolates of diverse serotypes. J Infect Dis I995, I 72:|408-|4I0.

10. Rhee SJ, Wilson KT, Gobert AP, Nataro JP, Fasano A: The enterotoxic activity of Shigella enterotoxin I (ShETI) is mediated by inducible nitric oxide synthase activity. J Pediatr Gastroenterol Nutr 200I, 33:400-4I6.

II. Frankel G, Riley L, Giron JA, Valmassoi J, Friedmann A, Strockbine N, Falkow S, Schoolnik GK: Detection of Shigella in feces using DNA amplification. J Infect Dis 1990, I 6 I: I 252-I 256.

12. Ménard R, Prévost MC, Gounon P, Sansonetti P, Dehio C: The secreted Ipa complex of Shigella flexneri promotes entry into mammalian cells. Proc Natl Acad Sci USA 1996, 93:1254-1258.

13. Hale TL: Genetic basis of virulence in Shigella species. Microbiol Rev 1991, 55:206-224.

14. Fasano A, Noriega FR, Maneval DR Jr, Chanasongcram S, Russell R, Guandalini S, Levine MM: Shigella enterotoxin I: an enterotoxin of Shigella flexneri $2 a$ active in rabbit small intestine in vivo and in vitro. I Clin Invest 1995, 95:2853-286I.

I5. Frankel G, Giron JA, Valmassoi J, Schoolnik GK: Multi-gene amplification: simultaneous detection of three virulence genes in diarrhoeal stool. Mol Microbiol 1989, 3:1729-1734.

16. Chiu CH, Ou JT: Rapid identification of Salmonella serovars in feces by specific detection of virulence genes, invA and spvC, by an enrichment broth cultivation-multiplex PCR combination assay. J Clin Microbiol 1996, 34:2619-2622.

17. Vargas M, Gascon J, De Anta MTJ, Vila J: Prevalence of Shigella enterotoxins $I$ and 2 among Shigella strains isolated from patients with traveler's diarrhea. J Clin Microbiol 1999, 37:3608-36II.
18. Gaudio PA, Sethabutr O, Echeverria P, Hoge CW: Utility of a polymerase chain reaction diagnostic system in study of the epidemic of shigellosis among dysentery patients, family contacts and well controls living in a shigellosis-endemic area. J Infect Dis 1997, I76:1013-1018.

19. Broude NE, Zhang L, Woodward K, Englert D, Cantor CR: Multiplex allele-specific target amplification based on PCR suppression. Proc Natl Acad Sci USA 200I, 98:206-2II.

20. Henegariu O, Heerema NA, Diouhy SR, Vance GH, Vogt PH: Multiplex PCR: critical parameters and step-by-step protocol. BioTechniques 1997, 23:504-5II.

21. Nataro JP, Seriwatana J, Fasano A, Maneval DR, Guers LD, Noriega F, Dubovsky R, Levine MM, Morris JG Jr: Identification and cloning of a novel plasmid-encoded enterotoxin of enteroinvasive Escherichia coli and Shigella strains. Infect Immun 1995, 63:472I-4728.

22. Sasakawa C, Kamata K, Sakai T, Murayama SY, Makino S, Yoshikawa $\mathrm{M}$ : Molecular alteration of the 140 -megadalton plasmid associated with loss of virulence and Congo red binding activity in Shigella flexneri. Infect Immun 1986, 5 I:470-475.

23. Venkatesan M, Buysse JM, Kopecko DJ: Use of Shigella flexneri $i p a C$ and $i p a H$ gene sequences for the general identification of Shigella spp. and enteroinvasive Escherichia coli. J Clin Microbiol 1989, 27:2687-269l.

24. Yavzori M, Cohen D, Wasserlauf R, Ambar R, Rechavi G, Ashkenazi $S$ : Identification of Shigella species in stool specimens by DNA amplification of different loci of the Shigella virulence plasmid. Eur J Clin Microbiol Infect Dis 1994, 13:232-237.

25. Houng HSH, Sethabutr O, Echeverria P: A simple polymerase chain reaction technique to detect and differentiate Shigella and enteroinvasive Escherichia coli in human feces. Diagn Microbiol Infect Dis 1997, 28:19-25.

26. DuPont HL, Levine MM, Hornick RB, Formal SB: Inoculum size in shigellosis and implications for expected mode of transmission. J Infect Dis 1989, I 59: I I26- I I 28.

\section{Pre-publication history}

The pre-publication history for this paper can be accessed here:

\section{http://www.biomedcentral.com/1471-2334/5/8/prepub}

Publish with Biomed Central and every scientist can read your work free of charge

"BioMed Central will be the most significant development for disseminating the results of biomedical research in our lifetime. "

Sir Paul Nurse, Cancer Research UK

Your research papers will be:

- available free of charge to the entire biomedical community

- peer reviewed and published immediately upon acceptance

- cited in PubMed and archived on PubMed Central

- yours - you keep the copyright

Submit your manuscript here:

http://www.biomedcentral.com/info/publishing_adv.asp
BioMedcentral 